\title{
1. Money laundering challenges in the African context: constitutions, law, politics and economics
}

\subsection{THE PROBLEM OF PEPs}

\subsubsection{The Cashgate Case}

Between 2009 and 2014 in Malawi, a number of government ministers and senior public officials manipulated the government payment control system, known as the Integrated Financial Management Information System (IFMIS). As a result, they were able to draw a series of fraudulent Government of Malawi cheques, the proceeds from which were either laundered through the purchase of real estate, expensive vehicles and other property in Malawi or paid in favour of numerous private contractors on the pretext that they had supplied goods and services to the government. In reality, none had been supplied. The transactions were then deleted from the IFMIS. Some US\$365 million was stolen and laundered. ${ }^{1}$ This became known as the Cashgate scandal.

The case is not an isolated one but neatly illustrates the manner in which huge sums of money can be looted from state coffers or acquired through other abuse of office and then laundered by politically exposed persons (PEPs). ${ }^{2}$ These are individuals who are or have been entrusted domestically with prominent public functions, family members and close associates. ${ }^{3}$ The term also includes members of ruling royal families. ${ }^{4}$

\footnotetext{
1 Figure provided by Victor Chiwala of the Malawi Anti-Corruption Bureau in a presentation to the Global Expert Group Meeting on Corruption involving Vast Quantities of Assets, 2018.

2 For a detailed account of such activity see Tom Burgess, The Looting Machine, William Collins, 2015.

3 See FATF 2012 Recommendations, General Glossary. For a full discussion see Section 2.4 below.

4 GIABA, Corruption-Money laundering nexus: An analysis of risks and control measures in West Africa, 2010 [54].
} 
As the Financial Action Task Force (FATF) has explained 'PEPs pose a high risk of money laundering by the very nature of their position'. 5 This inevitably involves 'grand corruption' i.e. 'acts committed at a high level of government that distort policies or the central functioning of the state, enabling leaders to benefit at the expense of the public good' ${ }^{6}$

Yet addressing the challenge effectively remains problematic and, as the Conference of States Parties (CoSP) to the UN Convention Against Corruption (UNCAC) has noted 'with regret' there is 'the risk that persons accused of crimes of corruption may escape justice and thus elude the consequences of their actions and may successfully hide their assets'. ${ }^{\text {? }}$

Combating the laundering of their proceeds of crime by PEPs demands a recognition that PEPs are a special case in that they are the most powerful political entities in any society with unique access to state assets and influence over state institutions. They are also in a position to control the anti-money laundering (AML) controls, for example by undermining the development and/or effectiveness of anti-corruption and anti-money laundering laws and institutions. ${ }^{8}$ In addition they have the power to undermine key constitutional AML safeguards by constitutional means, for example, through their power to appoint and remove heads of key AML institutions. ${ }^{9}$

\subsubsection{PEPs 'Don't Do It Alone'}

So-called 'syndicate corruption' can exacerbate the problem. Here a number of PEPs in positions of authority in various government institutions or ministries conspire to circumvent anti-corruption and AML control mechanisms: ${ }^{10}$ as in the Cashgate case. A further example comes from the East African Community (EAC) case in Uganda. Here PEPs located in the Ministry of the Public Service, the Office of the Administrator General, the Ministry of Finance and the Bank of Uganda combined to have billions of shillings paid as pensions and gratuities to 'ghost pensioners' and deceased pensioners of the defunct

\footnotetext{
5 FATF, Laundering the Proceeds of Corruption, Paris, 2011 [12].

6 Transparency International, 'How do you define corruption?' https://www .transparency.org/what-is-corruption\#define (accessed 6 June 2020).

7 Resolution $7 / 2$ 'Preventing and combating corruption in all its forms more effectively, including, among others, when it involves vast quantities of assets, based on a comprehensive and multidisciplinary approach, in accordance with the United Nations Convention against Corruption', 2017, Preamble.

8 See Section 2.5 below.

9 See Section 8.7 below.

10 Inspectorate of Government (Uganda), Bi Annual Report to Parliament, JanuaryJune 2017, pp. xi and 13.
} 
East African Community and Uganda protectorate. The PEPs then used the bank accounts of family members through which to launder the stolen funds. ${ }^{11}$

The syndicate may also include powerful individuals and families in the private sector through so-called 'state capture'. Thus in South Africa an allegedly corrupt relationship between PEPs, including the former President, Jacob Zuma and the Gupta family and their companies, led to state resources allegedly being diverted and laundered. ${ }^{12}$

The use of companies to assist in the laundering is also well established. Here PEPs use private companies they control to tender for government contracts without declaring their interest. Their power and influence over the process then facilitate the awarding of the contract to their company and the subsequent laundering of those assets, often to off-shore companies established for that purpose. ${ }^{13}$

\subsubsection{PEPs 'Can't Do It Alone'}

PEPs are often assisted by powerful individuals and institutions. For example, local as well as international financial institutions may facilitate the laundering of the dirty money. In the EAC case for example, the PEPs were assisted by senior managers at the Cairo Bank (U) Ltd, who facilitated the laundering of billions of Uganda shillings through opening fictitious bank accounts and filling in forged cash withdrawal slips purportedly signed by hundreds of 'pensioners' and then collected by a single individual posing as their agent. Professional money launderers, including lawyers and accountants may also facilitate the laundering. ${ }^{14}$

As regards the corporate sector, powerful multi-national corporate entities pay bribes (or are forced to pay bribes) to PEPs in order to obtain or retain business and are then often complicit in facilitating the laundering of the proceeds of corruption. ${ }^{15}$

11 Uganda v Lwamafa, 2018, unreported. Available at https://ulii.org/ug/judgment/ hc-anti-corruption-division-uganda/2018/11 (accessed 6 June 2020).

12 See Ivor Chipkin and Mark Swilling, Shadow State: The Politics of State Capture, Wits University Press, 2018. See also the case of Minister of Finance $v$ Oakbay Investments (Pty) Ltd and Others [2017] All SA 150 (GP) discussed at Section 5.4 .3 below.

13 See further the discussion in Chapter 12.

14 A point noted in the Lima Statement on Corruption involving Vast Quantities of Assets (December 2018). See further the discussion in Section 2.6.1 below.

15 See the Thiam case discussed in Section 2.1 below and generally Chapter 13. 


\subsection{THE ART OF PERSUASION AND THE THREE PRONG STRATEGY FOR COMBATING MONEY LAUNDERING BY PEPS IN AFRICAN STATES}

Combating money laundering by PEPs is a major on-going challenge facing all African states. This is why it is entirely appropriate to explore AML issues and strategies as they relate to all African states. Given their diversity it is not realistic to expect a uniformity of constitutions or any change in the fundamental principles of their national legal systems. Rather the aim must be to ensure that there is 'functional equivalence' at the national level. Thus states must 'to the extent possible, develop and harmonise their policies and domestic legislation' to combat money laundering ${ }^{16}$ 'according to their particular circumstances and constitutional frameworks'. ${ }^{17}$

This book therefore provides a critical analysis of the mechanisms and strategies required to combat the laundering of the proceeds of corruption by African PEPs and their operation in practice. Its aim is to provide ideas and strategies designed both to fight money laundering by PEPs and to facilitate the recovery of their proceeds of corruption.

Combating money laundering by PEPs requires a three prong approach i.e. effective action at the national, transnational and corporate levels.

\subsubsection{National Level}

Given the unique political, economic and financial power of those involved, combating money laundering by PEPs is not simply a matter of having in place constitutional safeguards and AML laws and institutions. These must be sufficiently 'persuasive' in order to make PEPs, financial institutions and other potential facilitators of money laundering comply with their AML obligations whether they want to or not. This means that all African states must adopt a multi-track approach as follows:

1. To ensure that their constitutions (as the supreme law) and constitutional bodies fulfil their key AML roles and are robust enough to withstand efforts by PEPs to undermine them. ${ }^{18}$

See Article 7(1) of the SADC Protocol Against Corruption.

Introduction to the FATF 2012 Recommendations.

See Section 6.2 below. 
This requires persuading PEPs to uphold constitutional values and to exercise their powers appropriately to ensure that the Constitution performs its role as an effective AML instrument. ${ }^{19}$

2. To have in place the necessary AML laws and institutions in line with their international obligations.

This requires 'persuading' all states to have in place appropriate AML laws as well as introducing and maintaining effective AML institutions. Some AML obligations are found in the UN Convention Against Transnational Organised Crime; the UNCAC and the African Union (AU) Convention on Preventing and Combating Corruption. ${ }^{20}$ However, through the work of the Financial Action Task Force and the African FATF-style regional bodies, all African states are part of the 'FATF family' and are subject to the AML requirements that are set out in the FATF Recommendations. ${ }^{21}$

3. To ensure that all FATF AML requirements are complied with in practice.

There is a need for effective mechanisms both to monitor the introduction and implementation of such laws and institutions and to hold individual states to account for non-compliance with their AML obligations. Whilst several international conventions contain useful monitoring provisions, the review process of the FATF and FATF-style African regional bodies provide a powerful and on-going persuasive function, including threats that a state which fails to comply will face serious adverse economic consequences. ${ }^{22}$

4. To recognise that civil society organisations (CSOs) play a vital role in overseeing the operation of the AML safeguards.

In particular, this includes what might be termed 'Constitution-watching'. CSOs have a key role in overseeing and protecting the operation of constitutional AML provisions and highlighting any attempt by PEPs to undermine them. 'Constitution-watching' is thus a potentially constructive and meaningful approach to preventing money laundering by PEPs.

9 This point is explored throughout the book.

See the discussion in Chapter 3.

See Chapter 4.

22 For example, the imposition of economic 'sanctions': see FATF Recommendation 19: see further Section 4.4 below. 


\subsubsection{Transnational Action}

Given the transnational nature of money laundering by PEPs, national AML efforts require the active support and co-operation of other states. ${ }^{23}$ The need to create the global political will to do so is essential through persuading all states to implement the appropriate legal, regulatory and operational AML measures. $^{24}$

\subsubsection{Corporate Action}

Given the involvement of private sector entities in paying bribes to PEPs and assisting in laundering the proceeds of crime, effective mechanisms to persuade even the most powerful entities to commit to good corporate governance is essential. ${ }^{25}$ These persuasive techniques consist of:

1. Gentle persuasion:

Here such entities are 'persuaded' to introduce effective codes of ethics that are designed to prevent both the payment of bribes to PEPs or involvement in laundering the proceeds of crime as well as a compliance regime designed to oversee its implementation. ${ }^{26}$

2. Forceful persuasion:

Here the bribe-paying company or the off-shore company used to launder the PEP's proceeds of crime is liable to criminal sanctions, whether in its 'home' jurisdiction or in the African victim state. ${ }^{27}$

3. Persuasive threats:

Debarment or the threat of debarment is a powerful economic weapon to 'persuade' the bribe-paying company to reveal all about its criminality. Debarment is the mechanism whereby a private legal entity or individual is prevented from tendering for, or participating in, projects funded, for example, by the African Development Bank, due to their involvement in corrupt practices. It is the fear

\footnotetext{
See Section 8.5 below.

24 This is the role of the FATF and the FATF-style regional bodies and is discussed throughout the book.

25 See Chapter 13.

26 See Section 13.5.2 below.

27 Their 'home' jurisdiction may be the place where they are registered or where they have a corporate presence. See Sections 13.3.1 and 13.3.2 below.
} 
Table 1.1 Framework for effective AML strategies against PEPS

\begin{tabular}{l|l|l}
\hline NATIONAL LEVEL & TRANSNATIONAL LEVEL & CORPORATE LEVEL \\
\hline $\begin{array}{l}\text { AML CONSTITUTIONAL } \\
\text { PROVISIONS AND BODIES }\end{array}$ & $\begin{array}{l}\text { INTERNATIONAL } \\
\text { CO-OPERATION } \\
\text { MECHANISMS }\end{array}$ & $\begin{array}{l}\text { CODES OF CONDUCT AND } \\
\text { COMPLIANCE MECHANISMS }\end{array}$ \\
\hline $\begin{array}{l}\text { AML AND ASSET RECOVERY } \\
\text { LAWS AND REGULATIONS }\end{array}$ & $\begin{array}{l}\text { INTER-AML AGENCY } \\
\text { CO-OPERATION }\end{array}$ & $\begin{array}{l}\text { PROSECUTION OF } \\
\text { BRIBE-PAYING COMPANIES }\end{array}$ \\
\hline AML BODIES & ASSET RECOVERY & DEBARMENT AND THE \\
- FINANCIAL INTELLIGENCE & MECHANISMS & THREAT OF DEBARMENT \\
UNITS & & \\
- AML REGULATORS & & \\
- ANTI-CORRUPTION & & \\
AGENCIES & & \\
\hline
\end{tabular}

of economic loss that motivates private sector entities not only to avoid bribe payments to PEPs but also to 'reveal all' to prosecutors. ${ }^{28}$

\subsubsection{Persuasive AML Techniques}

Persuasive techniques are therefore essential tools in developing the political will on the part of PEPs to combat money laundering and to exert economic and political pressure to deter both the bribe-payers and facilitators. It is the combination of effective constitutional AML provisions and laws coupled with the development of the political will and significant economic threats that offer the best prospect of combating money laundering by PEPs. The various strategies for achieving these AML goals are set out in Table 1.1.

\subsection{RATIONALE FOR THE BOOK}

In my book Combating Corruption: Legal Approaches to Supporting Good Governance and Integrity in Africa, ${ }^{29}$ I argued the need for 'persuasive' techniques designed to develop the necessary political will on the part of PEPs to maintain good governance laws and institutions and combat corruption. The book therefore explored, for example, the key anti-corruption strategies for maintaining integrity in both the public service and the private sector and the challenges of investigating corruption-related offences.

This book is essentially a companion work taking as its focus the challenging issue of combating money laundering by PEPs. As the Report of the High

28 See Section 13.3 .3 below.

29 Edward Elgar, 2014. 
Level Panel on Illicit Financial Flows from Africa puts it: 'the nature of actors, the cross border character of the phenomenon and the effects of illicit financial flows on the state and society attest to the political importance of the topic' ${ }^{30}$

In doing so, the book provides fresh insights into a number of vital issues:

- The relationship between constitutional rights and the AML requirements placed on countries by the FATF

- The potential role of national constitutions as AML instruments

- The strategies for challenging the power of PEPs to undermine constitutional AML safeguards

- The effectiveness of the FATF-style African regional bodies

- The effectiveness of financial intelligence units in African states

- The potential for developing a pan-African AML initiative

- The possibilities for introducing new AML techniques in African states.

There is considerable literature on money laundering particularly thanks to the numerous reports published by the FATF. ${ }^{31}$ The disclosures from the Panama Papers and the Luanda Papers coupled with the outstanding work of the International Consortium of Investigative Journalists (ICIJ) have focused the spotlight as never before on the way in which PEPs make use of facilitating states in order to conceal their beneficial ownership of companies and trusts. Similarly, there is considerable literature on 'safe haven' states. For example, the studies by Transparency International and Global Witness on the use of off-shore companies owned by PEPs to purchase real estate in London. ${ }^{32}$

What is much less well documented is the challenge of dealing with money laundering by PEPs in the African context in practice and this demands its own specific study ${ }^{33}$ Somewhat surprisingly, there is also little literature or indeed discussion on the relationship between national constitutions and AML laws and institutions. This book seeks to address these deficiencies.

The book is largely the result of library research supplemented by discussions with a wide range of practitioners both in and from numerous African states. Much of the discussion is based on the work of FATF and the African FATF-style regional bodies. In those parts of the book dealing with preven-

30 Report of the High Level Panel on Illicit Financial Flows from Africa Illicit Financial Flows, 2015, p. 65.

31 The topic also enjoys its own journal, i.e. the Journal of Money Laundering Law. See Section 12.4 below.

33 A recent book edited by Inge Amundsen, Political Corruption in Africa: Extraction and Power Preservation, Edward Elgar, 2019, provides a useful series of studies on the corruption and money laundering exploits of PEPs in several African countries. What it fails to do is provide any in-depth analysis of how to address these problems. 
tive national strategies, a comparative constitutional analysis is appropriate, particularly between Anglophone African states. This is facilitated by the fact that virtually all have constitutions based on the Westminster export model. ${ }^{34}$

Numerous case studies are included in order to highlight both the challenges and possible strategies for addressing money laundering. Critical studies on the operation of key constitutional safeguards are also included with the important supportive case law being considered. ${ }^{35}$

This is an exciting time to be writing on this topic with significant developments taking place, both nationally and internationally, designed to address money laundering by PEPs and to facilitate asset recovery. The following chapters will assess their impact in practice.

\subsection{ARRANGEMENT OF THE BOOK}

The book is divided into four parts.

Part I 'Setting the Scene' focuses on the challenges of addressing the problem of money laundering by PEPs.

Part II then explores the international and Africa-specific strategies designed to combat money laundering. Chapter 3 reviews the AML provisions in the UNCAC, the AU Convention on Preventing and Combating Corruption and other international and regional AML-related instruments. Chapter 4 then explores the role of the FATF and the African FATF-style regional bodies and critically reviews the implementation of the FATF Recommendations in African states with particular reference to PEPs. This includes an analysis of the impact and effectiveness of the monitoring provisions of the FATF.

Part III considers strategies for developing and maintaining effective AML strategies in African states. Chapter 5 considers the role and effectiveness of financial intelligence units in detecting money laundering and that of financial regulators and supervisors in overseeing compliance with AML obligations by financial and non-financial businesses and professions as laid down in the FATF Recommendations. Chapter 6 considers the role of constitutions and constitutional institutions in the fight against money laundering by PEPs. Chapter 7 focuses on the role and effectiveness of the Auditor General in preventing money laundering through overseeing transparency and accountability in public finances. Chapter 8 considers the constitutional protections enjoyed by PEPs and their impact on the investigative powers of law enforcement authorities, with particular reference to the requirements laid down in the

See Section 6.2 below.

35 See the case study of the Office of the Auditor General in Chapter 7 and the discussion on the use and abuse of the presidential power of pardon in Chapter 11. 
FATF Recommendations. Chapters 9 and 10 consider the constitutional rights of PEPs in relation to prosecution and asset recovery. Finally, Chapter 11 explores the use and abuse of the constitutional power of pardon especially when exercised in relation to PEPs.

Part IV then considers transnational AML initiatives in support of African states. Chapter 12 explores recent international developments on transparency in the beneficial ownership of companies whilst Chapter 13 assesses the developing mechanisms designed to persuade companies to 'reveal all' concerning their payment of bribes to PEPs to obtain or retain business and their assistance in laundering the proceeds of corruption. Chapter 14 examines the potential role of the African Court in combating money laundering by PEPs. Chapter 15 then provides an overview together with some final thoughts on further strengthening AML strategies in relation to African PEPs. 